\title{
Neotectonics of Brazzaville and Kinshasa: linking Congo Basin seismicity and in situ stress in the Inkisi Group
}

5

Hardy M.D. Nkodia ${ }^{1}$, Timothée. Miyouna ${ }^{1}$, Damien. Delvaux ${ }^{2}$, Florent. Boudzoumou ${ }^{1,3}$, Nicy. C. Bazebizonza Tchiguina $^{1}$

${ }^{1}$ Faculty of Sciences and Techniques, Department of Geology, Marien NGOUABI University, Brazzaville, P.o. 69, Republic of Congo.

$10{ }^{2}$ Department of Geology, Royal Museum for Central Africa, Leuvensesteenweg 13, B-3080 Tervuren, Belgium

${ }^{3}$ National Research Institute in Exact and Natural Sciences of Brazzaville, P.o. 2400, Republic of Congo (IRSEN).

Correspondence to: Hardy M.D. Nkodia (nkodiahardy@gmail.com)

Abstract. The Congo Basin has been affected by several earthquakes for which the in-situ stress has not yet been reported. This study aims to determine the in-situ stress related to earthquakes in the Congo Basin, particularly those located in the north portion of the Republic of Congo (RC) and in the northwest portion of the Democratic Republic of Congo (DRC). The combined analysis of seismic history of the Congo Basin and of in-situ paleo-

stress in the Inkisi Group allowed us to distinguish onshore earthquakes that are linked with preexisting zones of fractures on the continent and offshore earthquakes that are directly linked with transform faults. The Inkisi Group has been affected by two phases of strike-slip tectonics. The first phase, with a direction of compression $\mathrm{N} 142^{\circ}$, is a result of the Gondwanide orogenesis in the Paleozoic. The second phase, with a compression direction of N078 is related to the present-day stress of earthquakes in the Congo Basin. This phase is still active and is likely attributable to ridge push from the opening of the Atlantic Ocean. It is therefore appropriate that infrastructure construction in Brazzaville and Kinshasa considers seismic risk in the Inkisi bedrock of this area. As an example, we note that several masonry fences along the Congo river have developed fractures.

Keywords: Atlantic Ocean, Inkisi Group, Congo Basin, neotectonics, intraplate stress. 


\section{Introduction}

Brazzaville and Kinshasa are, respectively, capitals of the Republic of Congo (RC or Congo Brazzaville) and the Democratic Republic of Congo (DRC or Congo Kinshasa). Both countries are located on the passive western margin of the African plate. Although passive, this margin has experienced several recorded earthquakes(Ambraseys and Adams, 1986), some of which caused great damage. This was the case in Equatorial Guinea in 1983, where a 6.2 Richter scale magnitude earthquake resulted in nearly 300 deaths and 1,500 people injured (Ambraseys and Adams, 1986). Similar earthquake intensities were also reported in Cameroon and Gabon in 1945 and 1974, respectively (Ngatchou et al., 2018). These events illustrate that Central Africa, including both $\mathrm{RC}$ and DRC, are areas with potential risk of earthquakes. Unfortunately, the construction of major structures in Brazzaville and Kinshasa generally does not take this seismic risk into account, as no large-scale earthquakes have been recorded in these two cities. Indeed, recent studies on earthquakes in Congo Brazzaville (Ayele, 2002; Bouka Biona and Sounga, 2001) show that the epicenters coincide with faults delimiting the horsts and grabens of basement rocks in the Congo basin. Ayele, (2002) supports these assertions, and suggests that the earthquakes that occurred in March and April 1998 in the Congo Basin would be linked to an E-W compression resulting from the current opening of the Atlantic Ocean. However, this author notes in his study the inability to observe the active faults caused by these earthquakes and the resulting damage in Congo. Recently, structural studies conducted in the Inkisi sandstones (Delvaux et al., 2016; Miyouna et al., 2018; Nkodia, 2017) report the same stresses as those assumed by Ayele (2002). One of the tectonic phases highlighted by Miyouna et al. (2018) has been linked to ridge push resulting from the opening of the Atlantic Ocean.

The objectives of this study are, first, to determine the in-situ paleo-stresses in the Republic of Congo (RC) and the Democratic Republic of Congo (DRC), which are related to the stress of earthquakes reported in the Congo Basin; second, to show that earthquakes recorded in the north portion of the Congo Basin do indeed impact the cities of Brazzaville and Kinshasa, and probably also beyond Brazzaville in the department of Pool; third, to demonstrate that earthquakes recorded in the Central African area result from the opening of the Atlantic Ocean, with stress transfer into the continent through transform faults; finally, to influence Congolese decision-makers into taking seismic risk into account for the construction of large-scale structures.

\section{Geological overview}

This study was carried out on the Inkisi Group along the Congo River in the cities of Brazzaville and Kinshasa and along the Loufoulakari River, a tributary of the Congo River, in Louingui in the Pool department. Our study takes into account all available seismic data compiled from the Congo Basin in the area located between the latitudes $(-11.25,7.12)$ and the longitudes $(-18.1,23.51)$. These data are associated with several geological units within Central Africa (Fig. 1), mostly in the Congo Basin.

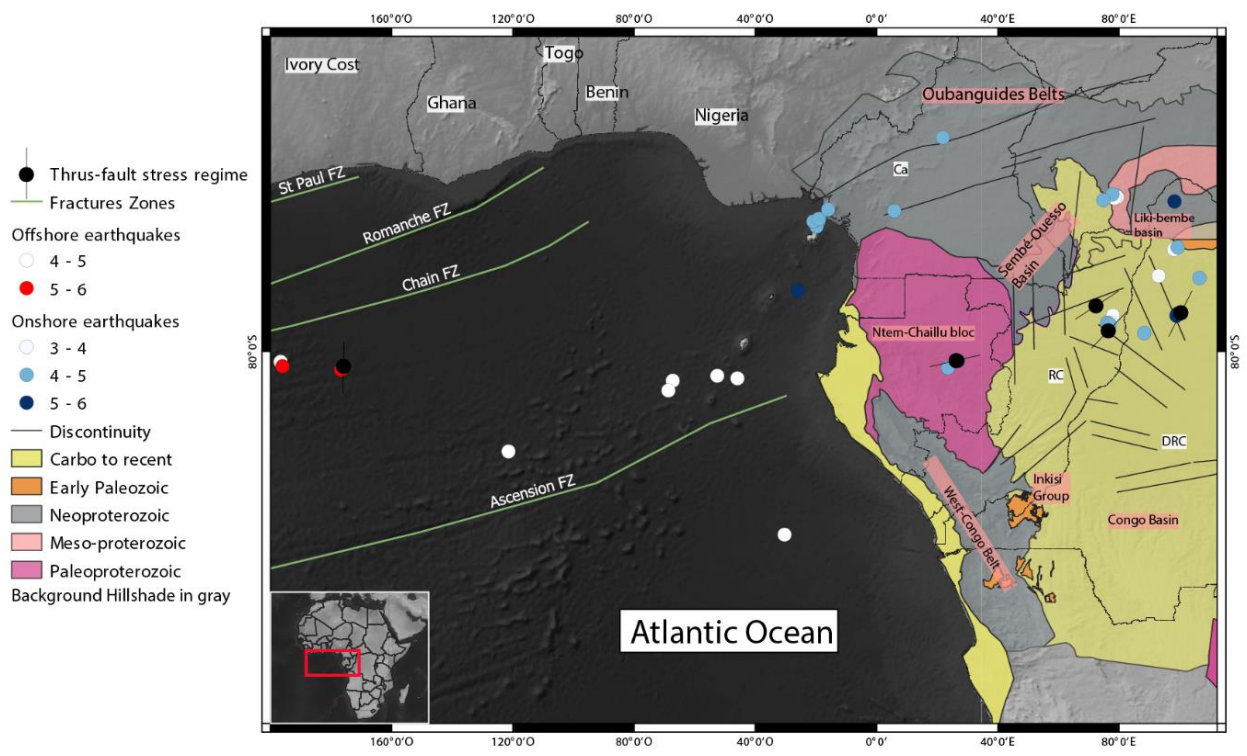


75 Figure 1 : Map of the study area and earthquakes. Ca: Cameroon; RC Republic of Congo, DRC: Democratic Republic of Congo. Discontinuities on the map come from the work of Sabata, (2014), and the earthquakes from USGS-earthquake data (https://earthquake.usgs.gov/). The mapping of compressive stress regimes comes from the world stress map (O Heidbach et al., 2016). The transform fault zones were redrawn from the work of Heine et al. (2013).

Geologic rock units of the Republic of Congo (RC) and the Democratic Republic of Congo (DRC) range in age from Precambrian to recent and have recorded several geological events. These events include the development of the Congo Craton (Brito Neves et al., 1999), the Pan-African orogeny (Boudzoumou and Trompette, 1988; Cosson, 1955; Dadet, 1969), the development of the Congo basin (Crosby et al., 2010; Giresse, 1982, 2005a; Kadima et

85 al., 2011) and the opening of the Atlantic Ocean (Guiraud et al., 2005; Wilson, 1966). All of these events resulted in fracture zones (Alkmim et al., 2006; Heine et al., 2013; Moulin et al., 2010) that are likely to be reactivated by lithospheric dynamics.

The cities of Brazzaville and Kinshasa and the sub-prefecture of Louingui have the same underlying geology on both sides of the Congo River. The subsurface of these regions is made up of the following four geological units from bottom to top: (1) the Inkisi Group, which rests in angular unconformity on the formations of the West Congo belt. This Group is made up quartzo-feldspathic sandstones of fluvial origin, ranging from Cambrian to pre-Karoo age (Boudzoumou, 1986 ; Tack et al., 2008 ; Callec et al., 2015). The Inkisi Group outcrops south of Brazzaville and Kinshasa along the Congo River and in the department of Pool. It extends into DRC and Angola. The Inkisi Group is correlated with the Banalia and Banio Group on the eastern and northeastern edge of the Congo Basin (Linol et al., 2015). The Inkisi Group is overlain by (2) the Stanley Pool Group, which is essentially composed of sands and fossiliferous clays of fluvio-lacustrine origin (Callec et al., 2015). This Group is only encountered by subsurface drilling. Above the Stanley Pool Group is (3) the Batéké Group, which is comprised essentially of quartzo-feldspathic sands in the lower Batéké (Bat1), which is the lateral equivalent of polymorphic sandstones in Kinshasa and loose sands in the upper Batéké ( Bat2), which correspond to the Neogene of Kinshasa. (4) All of these units are covered by the yellow ocher sands of the Cover Formation (Miyouna et al., 2016, 2019).

The Congo Basin area is delimited by several cratonic blocks (Fig. 2). To the west the basin is delimited in the Congo craton with the Ntem and Chaillu blocks, respectively, in Gabon and RC. To the southeast the basin is bounded by the Kasai blocks and to the northeast by the Tanzanian blocks. These blocks are of Archean to Proterozoic age. They include magmatic, volcano-sedimentary deposits and metamorphic complexes. The Congo basin would have been developed by a displacement of the Kasaï block towards the south, along a dextral NE-SW strike slip fault in the Proterozoic (Giresse, 1982). Within the basin, individual aborted rifts resulted in structure development during Meso-Proterozoic to Neoproterozoic age, including the Sembée-Ouesso basin (Boudzoumou and Trompette, 1988); the Lindi basin, and the Liki-Bembe basin (Delpomdor and Préat, 2015). 


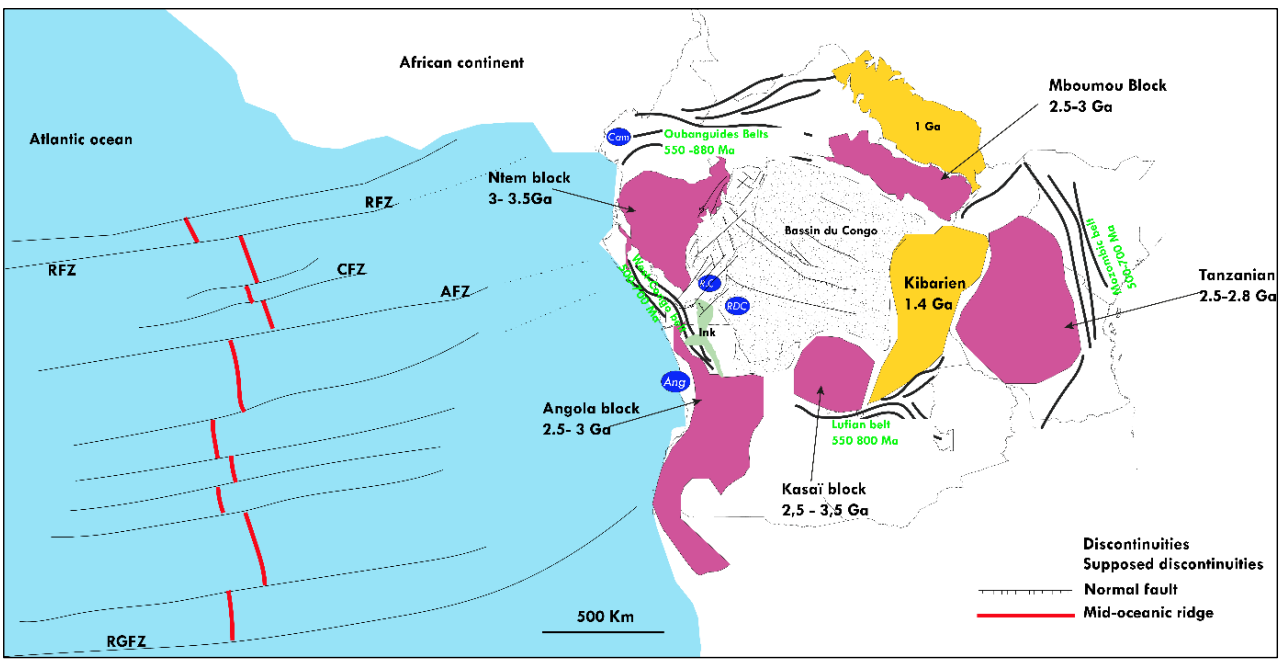

Figure 2: Simplified structural map of the location of the Congo Basin and major structures around and in the basin. RFZ, CFZ, AFZ and RGFZ, respectively the transform fault zones of Romanche, Chain, Ascension and Rio de Grande. The areas of discontinuities come from the work of Sabata, (2014). The transform faults were redrawn from the work of (Heine et al., 2013)

\section{Study Methodology}

The methodology consisted of four steps: the first focused on data collection and localization of earthquakes that have occurred on the west-equatorial margin of the Atlantic Ocean from 1971 through 2019, as reported in the USGS earthquake research catalog of the United States Geological Survey (https://earthquake.usgs.gov/) . The second step consisted of downloading in MS Excel format compiled data of world stresses in the earth's crust from the website: www.world-stress-map.org. Third, we utilized a geographic information system to map the location and concentration of earthquake zones on the continent and in the ocean. We superimposed the major fractures and lineaments of the Congo Basin and the transform fault zones of the Atlantic Ocean with earthquake locations in order to determine the possible sources of these earthquakes.

Fourth, we utilized Equation 1, below, to calculate the recurrence (I) of each event and its number of occurrences, where $\mathrm{m}$ corresponds to the number of occurrences of the event and $\mathrm{N}$ is the total number of years since the occurrence of the event. Eq. (1)

$$
I=\frac{N+1}{m},
$$

130 Fifth, we determined the paleo-stresses that have affected the Inkisi Group by using the numerical inversion method (Angelier, 1989, 1994), using the Win-Tensor program with data obtained from the field study. This method is based on the determination of stress tensors which minimize the difference between the theoretical striae and the calculated striae of each fault. It is described in Delvaux and Sperner, (2003) and allows reconstruction of four (4) parameters of the reduced stress tensor: the orthogonal orientation of the main stress axes $\sigma 1 ; \sigma 2 ; \sigma 3$ (where $\sigma 1 \geq \sigma 2 \geq \sigma 3)$ and the ratio $\mathrm{R}=(\sigma 2-\sigma 3) /(\sigma 1-\sigma 3)$ (where $0<\mathrm{R}<1)$. An index $\mathrm{R}^{\prime}=2-\mathrm{R}$ allows one to determine the stress regime of any tensor (Fig. 3). From field criteria (overlap relation, conjugate faults etc.) (Dunne and Hancock, 1994) and those of the software (Delvaux and Sperner, 2003), we determined the chronology of the different phases of deformation. 


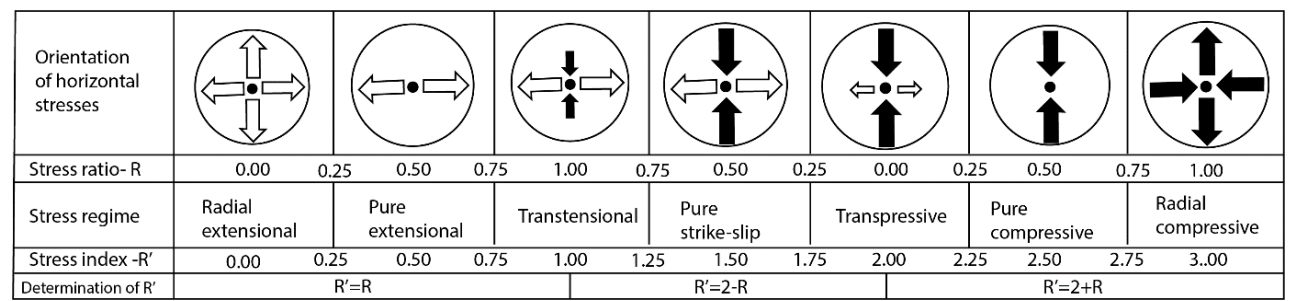

Figure 3 : Value of the stress index R' with respect to the stress regime. Modified from (Delvaux et al., 1997)

\section{Results}

\subsection{In situ stress of Inkisi Group}

\subsubsection{Field Characterization.}

The Inkisi Group displays two fracture systems. The first system is made up of a set of NW-SE joints (Fig. 4a) and conjugate strike slip faults that are associated dominantly with NW-SE sinistral strike slip (Fig. 4a) and a few of dextral E-W strike slip (Fig.8a). In the field, joints have been observed with plumose structures on their surfaces (Fig. 4c) that are parallel to strike slip faults. The second system of fractures consists of essentially NE-SW joints (Fig. 6a) and a group of conjugate strike slip faults that are associated dominantly with NE-SW dextral strike slip (Fig. 4 d) and a few with E-W to WNW-ESE sinistral strike slip (Fig. 8b). The two systems can be distinguished as separate features because the second system offsets the first system by 2 to $12 \mathrm{~cm}$ in different observed locations, particularly in Brazzaville and Kinshasa. In this study, our observations only made it possible to characterize the first and second systems in Brazzaville; in Louingui and Kinshasa, only the second system was studied.
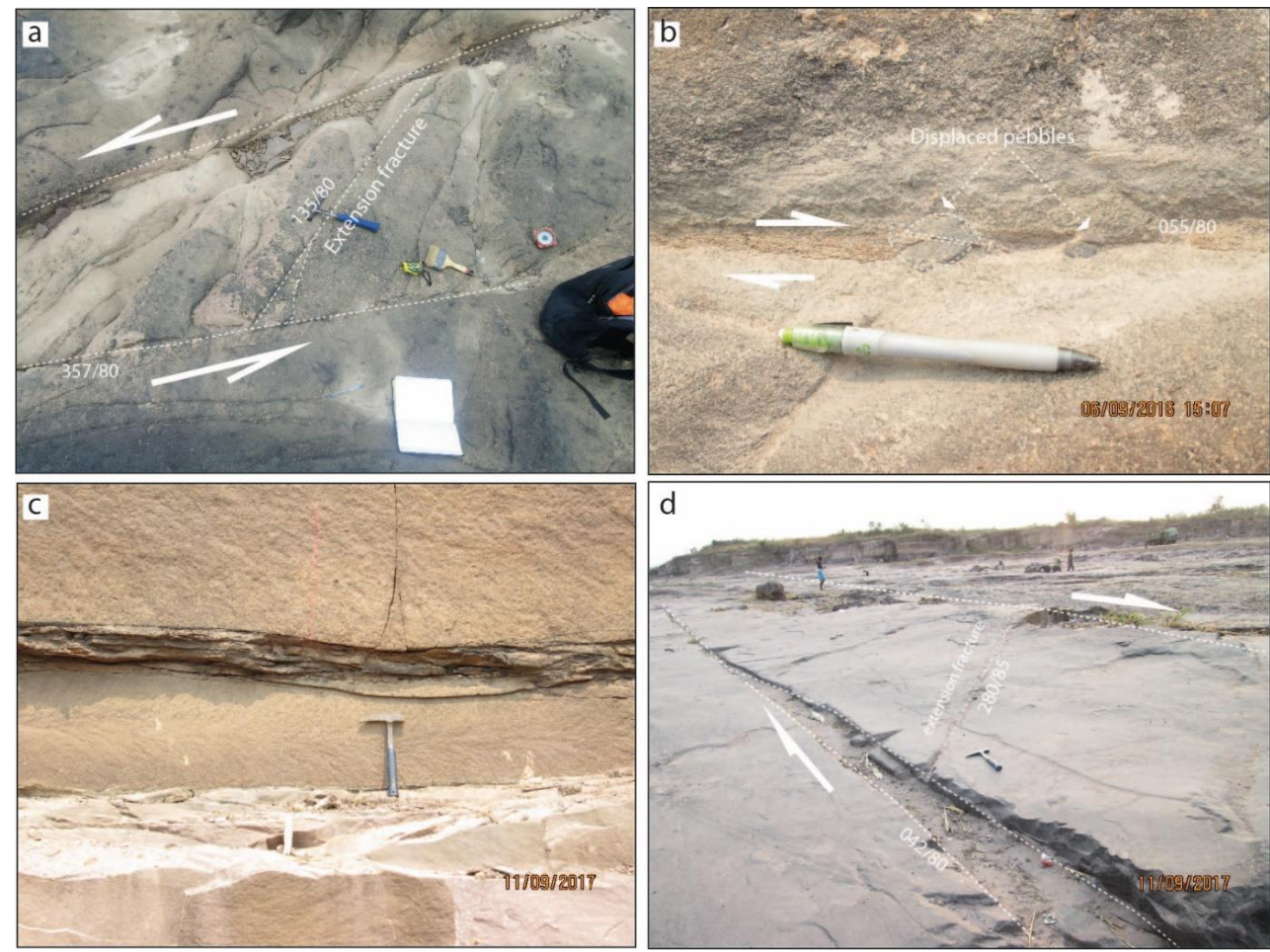

Figure 4 : Faults and joints in the field. (a) a sinistral strike slip fault zone of the first system. The corridor is associated with extension fracture (b) A dextral strike slip fault associated with displaced pebbles (c)Joint surface with plumose structures. (d) A dextral strike slip fault zone with extension fractures in the corridor. 

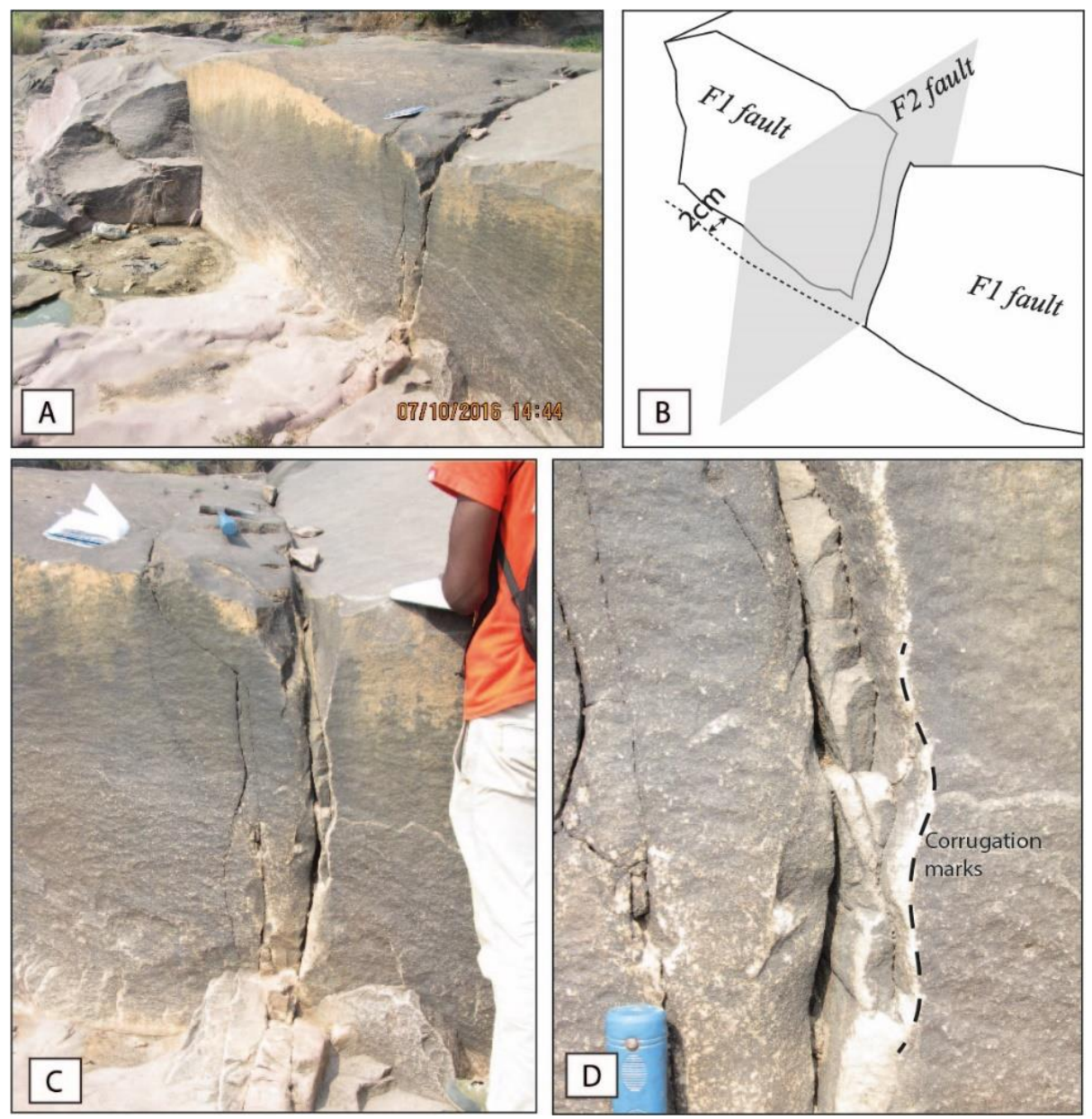

Figure 5 : Cross-cutting relation between the first and the second systems of fracture. (A) Crosscutting zone (B) interpretation of the cross-cutting zone, F1 fault of the first system is offset over $2 \mathrm{~cm}$ by F2 Fault of the second system. (C) Profile view of the cross-cutting zone. (D) Development of corrugation in the cross-cutting zone

Homes in Brazzaville have been affected by movement along several tectonic-related bedrock fractures along the Congo River. Observed linear breaks in concrete and masonry walls and fences frequently occur as a continuation of fractures or faults affecting the Inkisi sandstones (Fig. 6). Such linear breaks and fractures showed mostly E-W to NE-SW orientation. According to residents, the cracks reoccur on houses and fences despite several repairs, as shown in Figure 6. 


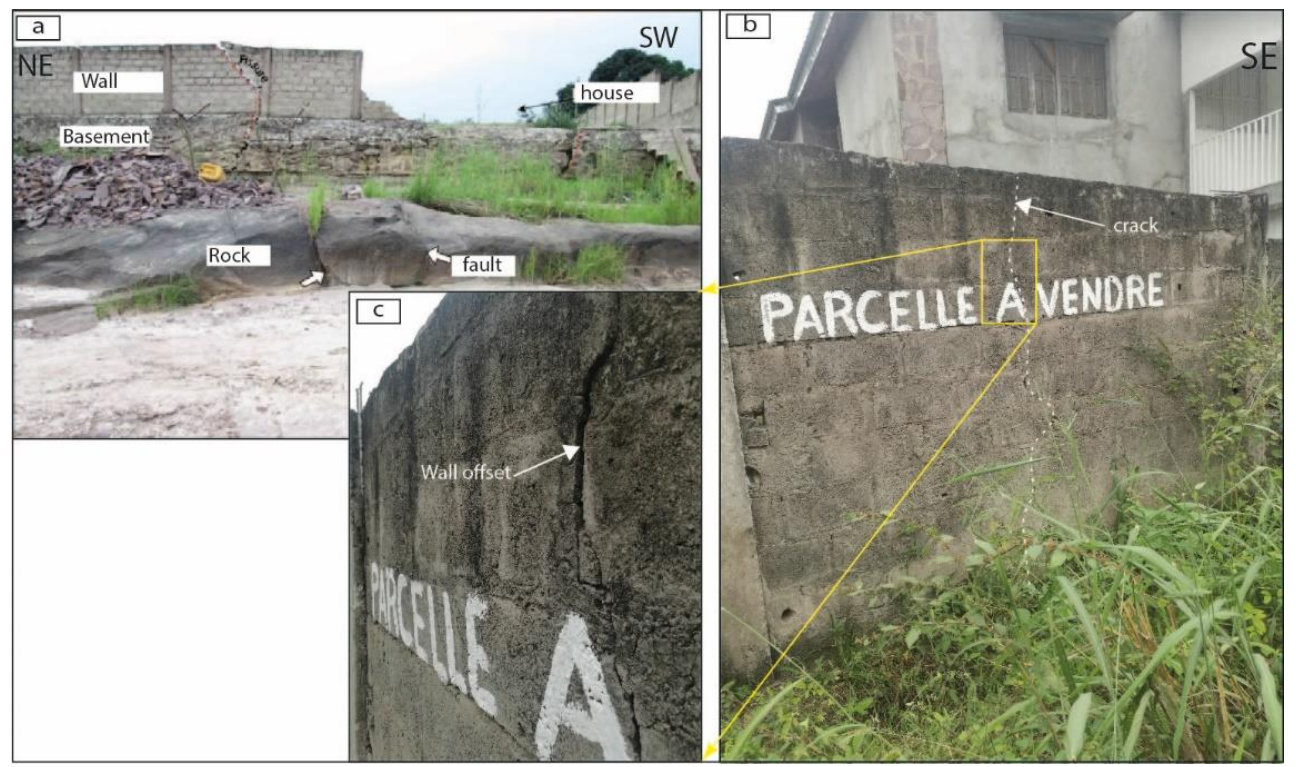

170 Figure 6 : : Home linear breaks. (a) Linear breaking of a fence in parallel direction with faults in the sandstones of the Inkisi sandstones. Fractures even affect the foundation of the fence. (b) Home placed for sale due to the appearance of linear breaks (c) A lateral movement along the wall of the fence.

\subsubsection{Stress inversion}

We determined four tensors associated with two stress stages:

- The first stress stage started with the development of NW-SE joints. Their evolution then developed into systems of conjugate strike slip faults oriented NW-SE (sinistral) and E-W (dextral). The development of joints indicates a tensor consistent with an extension regime oriented NE-SW and a compression direction acting NW-SE (Fig.7a). The evolution of joints into strike slip faults is indicated by a slight rotation of the stress with a new-determined tensor, indicating a NW-SE compression in a strike slip regime (Fig. 8a). Evidence of this well-constrained stage was only found in Brazzaville.

- The second stress stage also started with the development of NE-SW joints (Fig. 7b), which then evolved into a system of conjugate strike slip faults oriented NE-SW (dextral) and WNW-ESW to E-W (sinistral). The development of joints is indicated by a stress tensor with an extension regime oriented NW-SE (Fig. 
7b). These joints have evolved into a strike slip regime whose the tensor indicates horizontal E-W compression in Brazzaville, Kinshasa and Louingui (Fig. 8b, c, d).
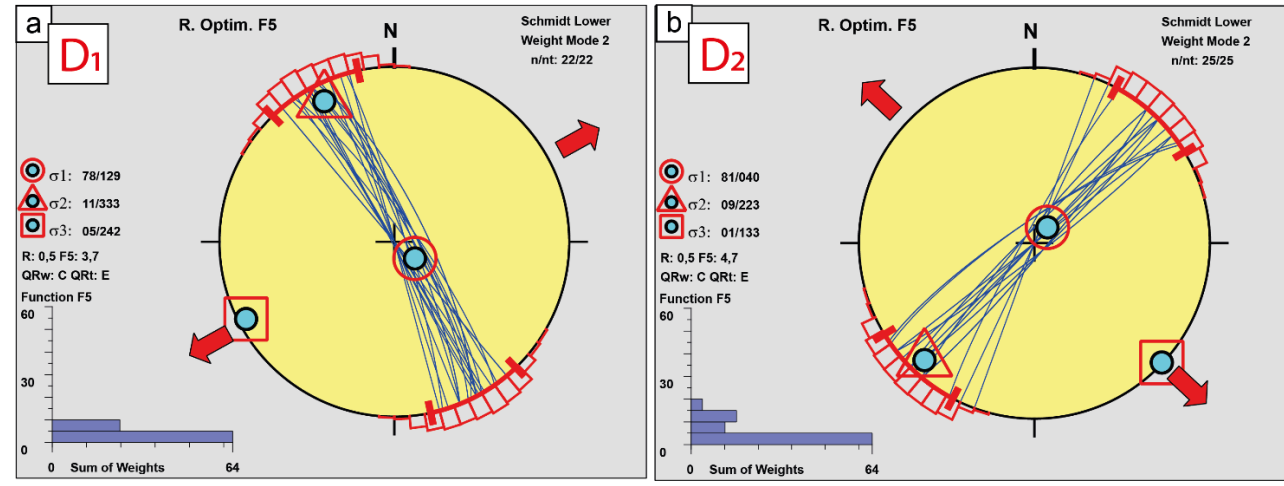

Figure 7 : Tensor and phases of deformation associated with joints. (a) Beginning of the first phase by an extension regime. (b) Beginning of the second phase by an extension regime.
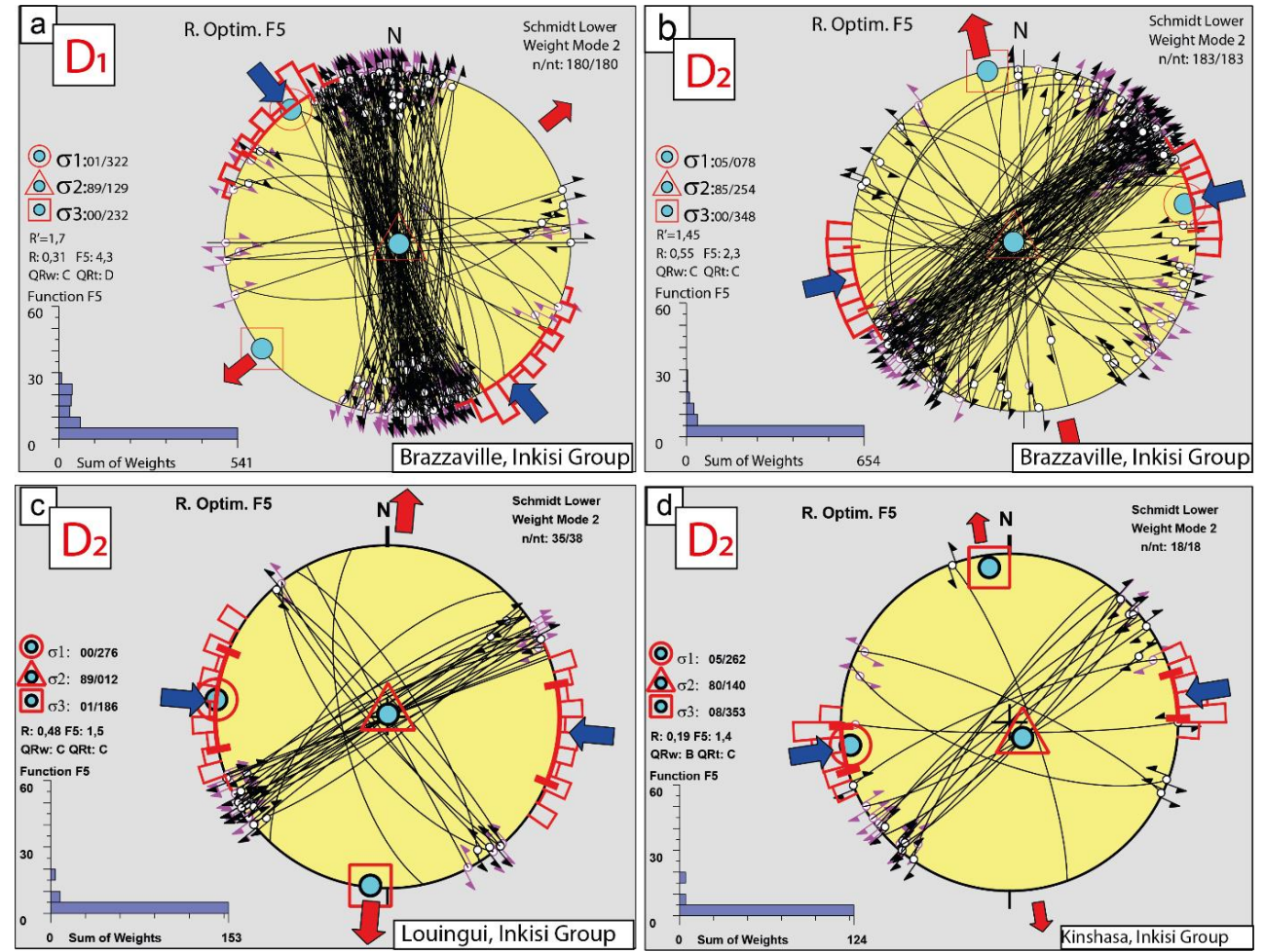

Figure 8 : Stress tensors and different resulting phases of deformation. (a) and (b) The first and second tectonic phases, determined at Brazzaville, in RC. (c) and (d) second phase of deformation determined respectively at Kinkala, in RC, and Kinshasa, in RDC.

Table 1: Stress tensors for different stress stages. $\mathrm{N}$ : the number of faults $\&$ fractures recorded ; nt : the total number of faults used ; $\sigma 1, \sigma 2, \sigma 3$ : stress axes ( $\mathrm{pl}:$ plunge, Az : azimuth) ; R : stress-ratio, $\alpha$ : weighed mean misfit angle between observed and modeled slip directions. The regime and the index regime $\mathrm{R}^{\prime}$ and $1 \sigma$ standard 
deviation of R'. Reg : stress regime as in stress world map (NF : normal faulting, SS : strike-slip, NS : normal

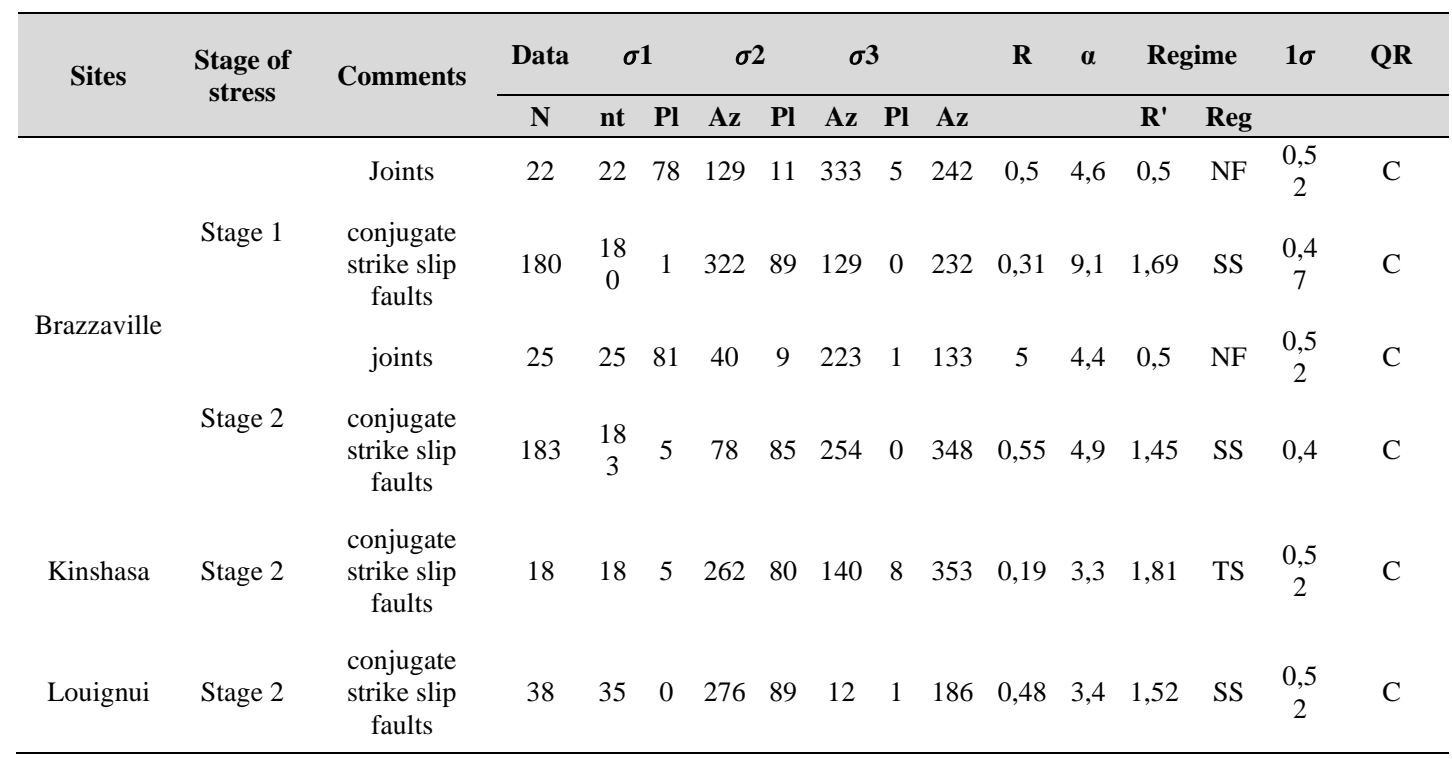

4.2 Analysis of existing seismic data

Analysis of earthquake location data (Table 2) indicates that the passive western margin of the Atlantic Ocean has been affected by several earthquakes. These earthquakes can be grouped into two zones: onshore earthquakes and offshore earthquakes.

Table 2: Earthquake data in the study area (source: https://earthquake.usgs.gov/)

\begin{tabular}{|c|c|c|c|c|c|}
\hline Year & Time & Latitude & Longitude & Depth (Km) & Magnitude \\
\hline 2019 & 2019-12-19T15:25:58.816Z & 18.052 & 8.184 & 10 & 5.5 \\
\hline & 2019-09-06T11:29:40.330Z & -0.2855 & -6.6324 & 10 & 4.7 \\
\hline $\begin{array}{l}2019 \\
2018\end{array}$ & 2018-12-10T20:48:00.230Z & -0.7144 & 5.8186 & 10 & 4.4 \\
\hline 2018 & 2018-04-18T13:07:20.180Z & -0.4104 & -6.5808 & 10 & 5 \\
\hline 2016 & 2016-04-14T16:44:33.580Z & -0.5373 & -11.582 & 10 & 5.2 \\
\hline 2016 & 2016-03-04T18:40:09.460Z & -0.8539 & 4.5183 & 15.61 & 4.6 \\
\hline 2014 & 2014-01-26T06:20:21.280Z & 22.486 & 188.691 & 9.66 & 4.2 \\
\hline 2013 & 2013-08-20T20:19:48.430Z & -2.8749 & -0.2473 & 7.16 & 4.7 \\
\hline 2013 & 2013-04-15T01:38:19.790Z & -5.417 & 7.761 & 10 & 4.1 \\
\hline 2010 & 2010-05-26T13:03:46.130Z & -0.793 & 6.409 & 10 & 4.5 \\
\hline 2005 & 2005-06-10T01:07:43.190Z & 4.647 & 17.628 & 10 & 4.5 \\
\hline 2005 & 2005-06-10T01:00:10.830Z & 4.597 & 17.643 & 10 & 4.3 \\
\hline 2005 & 2005-06-10T00:36:53.890Z & 4.57 & 17.565 & 10 & 3.9 \\
\hline 2005 & 2005-06-09T13:57:08.950Z & 4.683 & 17.504 & 10 & 4.7 \\
\hline 2005 & 2005-03-19T11:49:18.440Z & 4.181 & 11.023 & 10 & 4.6 \\
\hline 2005 & 2005-01-13T10:04:57.690Z & 0.64 & 17.391 & 10 & 4.6 \\
\hline 2002 & 2002-03-18T18:34:41.020Z & 1.077 & 17.514 & 10 & 3.4 \\
\hline
\end{tabular}




\begin{tabular}{rlrrrr}
2002 & $2002-08-18 \mathrm{~T} 04: 53: 12.910 Z$ & -0.549 & -8.933 & 10 & 4.2 \\
2000 & $2000-03-25 \mathrm{~T} 15: 48: 06.110 Z$ & 0.853 & 17.453 & 10 & 4 \\
1999 & $1999-03-28 \mathrm{~T} 20: 38: 52.150 Z$ & 3.827 & 8.764 & 10 & 4.9 \\
1999 & $1999-03-28 \mathrm{~T} 20: 12: 34.800 Z$ & 3.701 & 8.728 & 10 & 4.8 \\
1999 & $1999-03-27 \mathrm{~T} 22: 32: 45.250 Z$ & 3.928 & 8.777 & 10 & 4.7 \\
1999 & $1999-03-27 \mathrm{~T} 19: 03: 56.140 Z$ & 3.853 & 8.628 & 10 & 4.7 \\
1999 & $1999-03-27 \mathrm{~T} 18: 04: 43.560 Z$ & 3.931 & 8.798 & 10 & 4.8 \\
1998 & $1998-04-26 \mathrm{~T} 14: 16: 52.200 Z$ & 0.855 & 17.342 & 10 & 5.2 \\
1998 & $1998-03-05 \mathrm{~T} 02: 59: 43.360 Z$ & 0.814 & 17.418 & 10 & 5.1 \\
1995 & $1995-09-25 \mathrm{~T} 17: 04: 49.290 Z$ & 1.12 & 19.424 & 10 & 5.5 \\
1995 & $1995-09-22 \mathrm{~T} 08: 51: 49.550 Z$ & 1.065 & 19.395 & 10 & 5.4 \\
1995 & $1995-06-08 \mathrm{~T} 20: 47: 59.040 Z$ & 3.033 & 19.326 & 10 & 4.3 \\
1995 & $1995-06-08 \mathrm{~T} 19: 45: 54.970 Z$ & 3.096 & 19.438 & 10 & 4.4 \\
1990 & $1990-09-20 \mathrm{~T} 12: 13: 25.410 Z$ & 4.208 & 9.062 & 10 & 4.7 \\
1988 & $1988-01-07 \mathrm{~T} 22: 55: 53.920 Z$ & 0.549 & 18.442 & 33 & 4.8 \\
1987 & $1987-01-26 \mathrm{~T} 23: 11: 33.470 Z$ & 6.373 & 12.453 & 10 & 4.9 \\
1986 & $1986-06-17 \mathrm{~T} 06: 30: 12.840 Z$ & 4.885 & 21.103 & 10 & 4.5 \\
1983 & $1983-06-18 \mathrm{~T} 02: 09: 35.090 Z$ & -1.143 & 4.39 & 10 & 4.8 \\
1981 & $1981-08-20 \mathrm{~T} 19: 41: 09.690 Z$ & -0.18 & 21.728 & 33 & 4.8 \\
1981 & $1981-07-23 \mathrm{~T} 06: 21: 52.020 Z$ & 2.183 & 20.076 & 12.6 & 4.7 \\
1979 & $1979-11-01 \mathrm{~T} 21: 50: 46.900 Z$ & 2.627 & 22.132 & 10 & 4.6 \\
1979 & $1979-01-09 \mathrm{~T} 00: 26: 46.100 Z$ & 4.511 & 17.24 & 33 & 4.6 \\
1976 & $1976-05-15 \mathrm{~T} 08: 09: 57.200 Z$ & 4.461 & 19.348 & 23 & 5.6 \\
1976 & $1976-03-12 \mathrm{~T} 15: 59: 13.600 Z$ & -0.487 & 12.624 & 33 & 5.2 \\
1974 & $1974-09-23 \mathrm{~T} 19: 28: 17.200 Z$ & -0.278 & 12.917 & 33 & 6.2 \\
1971 & $1971-09-30 \mathrm{~T} 21: 24: 10.000 Z$ & -0.514 & -4.956 & 15 & 5.8 \\
\hline & & & & &
\end{tabular}

The USGS earthquake catalog lists forty-three (43) earthquakes recorded in the area of this study with magnitudes between 3.4 and 6.2 (Fig. 9a) on the Richter scale. Earthquakes of magnitude 4 to 5 have been most frequent (Fig. 9c). The most intense earthquake took place in central Gabon with a magnitude of 6.2 in 1974. In RC, the majority of earthquake epicenters were located in the south portion of the Likouala department. In the DRC, six (6) earthquakes are listed. The first listed earthquake in DRC took place in 1998 and the last in 2014. The epicenters of these quakes are mainly located in the northwest portion of the country and have magnitudes that vary between 4 and 5 (Fig. 9d). 

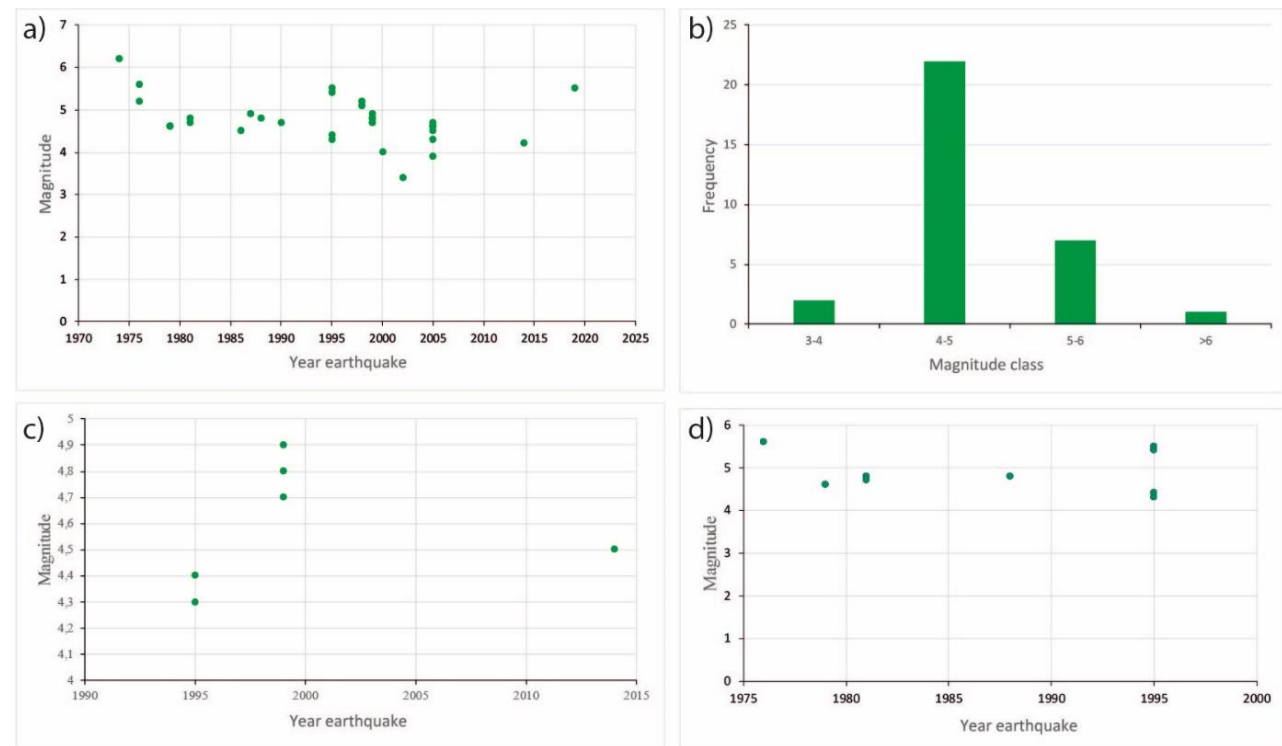

Figure 9 : Relationship between earthquakes and their years of occurrence in the Congo Basin. (a) earthquakes throughout the study area. (b) the frequency of earthquakes throughout the study area. (c) earthquakes in relation to their magnitude in RC. (d) earthquakes in relation to their magnitude in the DRC.

Table 1 : Recurrence of earthquakes in the study area

\begin{tabular}{c|c|c}
\hline \hline Magnitude & Occurences & $\begin{array}{c}\text { Reccurrence Interval } \\
\text { (years) }\end{array}$ \\
\hline \hline $6+$ & 4 & 12 \\
$5-6$ & 21 & 2 \\
$4-5$ & 6 & 8 \\
$3-4$ & 1 & 46 \\
\hline \hline
\end{tabular}

In the onshore domain, two zones of earthquake concentrations (Fig. 10) are observed: the first zone of concentration of seismic epicenters $(\mathrm{C} 1)$ is located in the northwest Congo basin; the second zone $(\mathrm{C} 2)$ is located in the southwest of Cameroon in the Oubanguides chain. In the first zone (C1), the seismic epicenters line up in the NE-SW and NW-SE directions. In the second zone (C2), the earthquake epicenters line up along the Central African Shear Zone (CASZ).

\section{Offshore earthquakes}

Offshore earthquakes of the western Atlantic Ocean margin (Fig. 10) align with the main transform fault zones. We noted eleven (11) earthquakes in the study area. The magnitudes of these earthquakes do not exceed five (5) on the Richter scale. The transform fault "Chain" of sinistral movement and the transform fault "Ascension" of dextral movement, respectively, form continuities that are easily followed up to zones C1 and C2 (Fig. 10). 


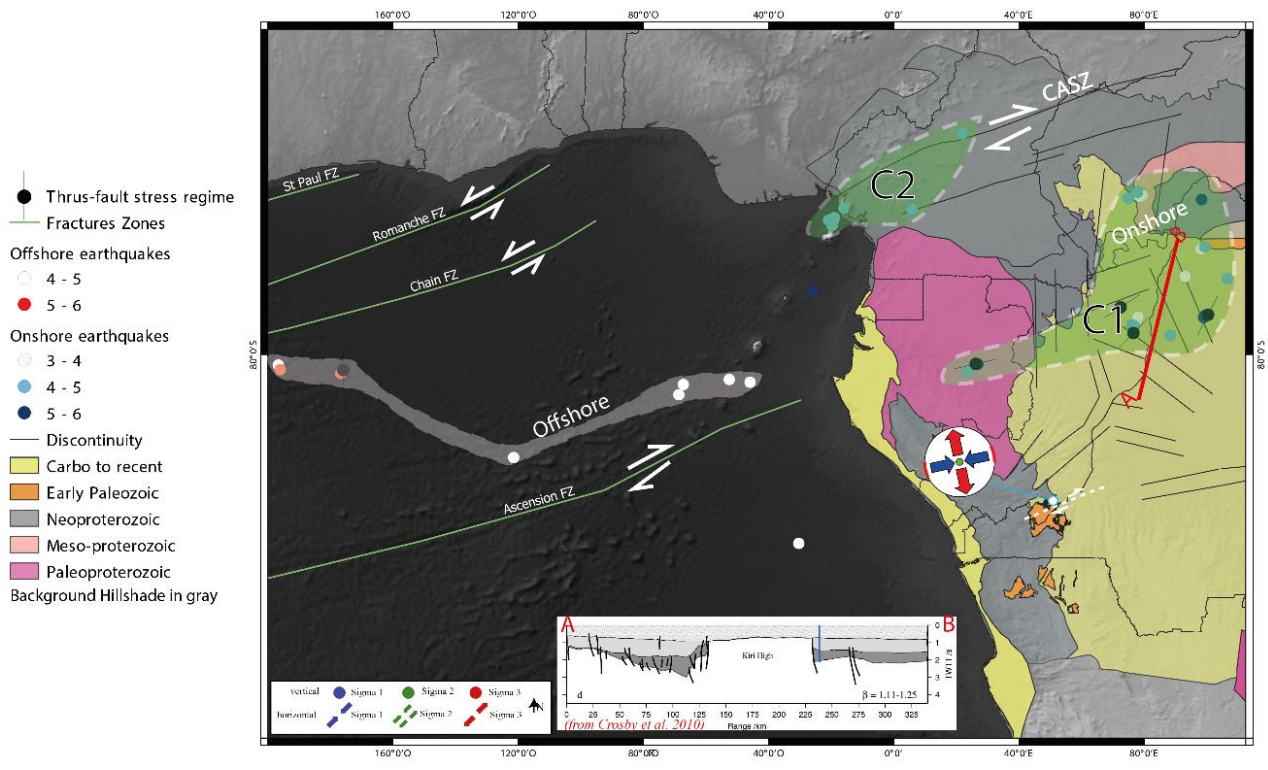

Figure 10 : Earthquake distribution map in the study area. The second stress stage obtained on the Inkisi Group is parallel to that obtained from focal mechanism for earthquakes. Two areas of concentration are distinguished. The zones of discontinuities come from the work of (Sabata, 2014)), and the earthquakes from USGS-earthquake (https://earthquake.usgs.gov/). The mapping of compressive stress regimes comes from the world stress map (Heidbach et al., 2016). The transform faults zones were redrawn from the work of (Heine et al., 2013)

Data on world stress regimes, obtained from focal mechanisms (Heidbach et al., 2016, 2018) in RC and Gabon, showed that a compressive regime is active in the north and the northeast of the RC (Fig. 10), as well as in central Gabon.

The azimuth of the crustal stress varies from the mid-oceanic ridge to the continent. It is compressive and horizontal, oriented E-W $\left(084^{\circ}\right)$ at the mid-oceanic ridge then gradually becomes NE-SW $\left(077^{\circ}\right.$ to $\left.044^{\circ}\right)$ in the seismic zone C1 (Fig. 10, A-A '). However, at latitudes further south towards the northeast of Angola, this variation is weak over $3676 \mathrm{~km}$ (Fig. 11, B-B'); the crustal stress goes only from $082^{\circ}$ azimuth to $097^{\circ}$ from the mid-oceanic ridge to the continent. 


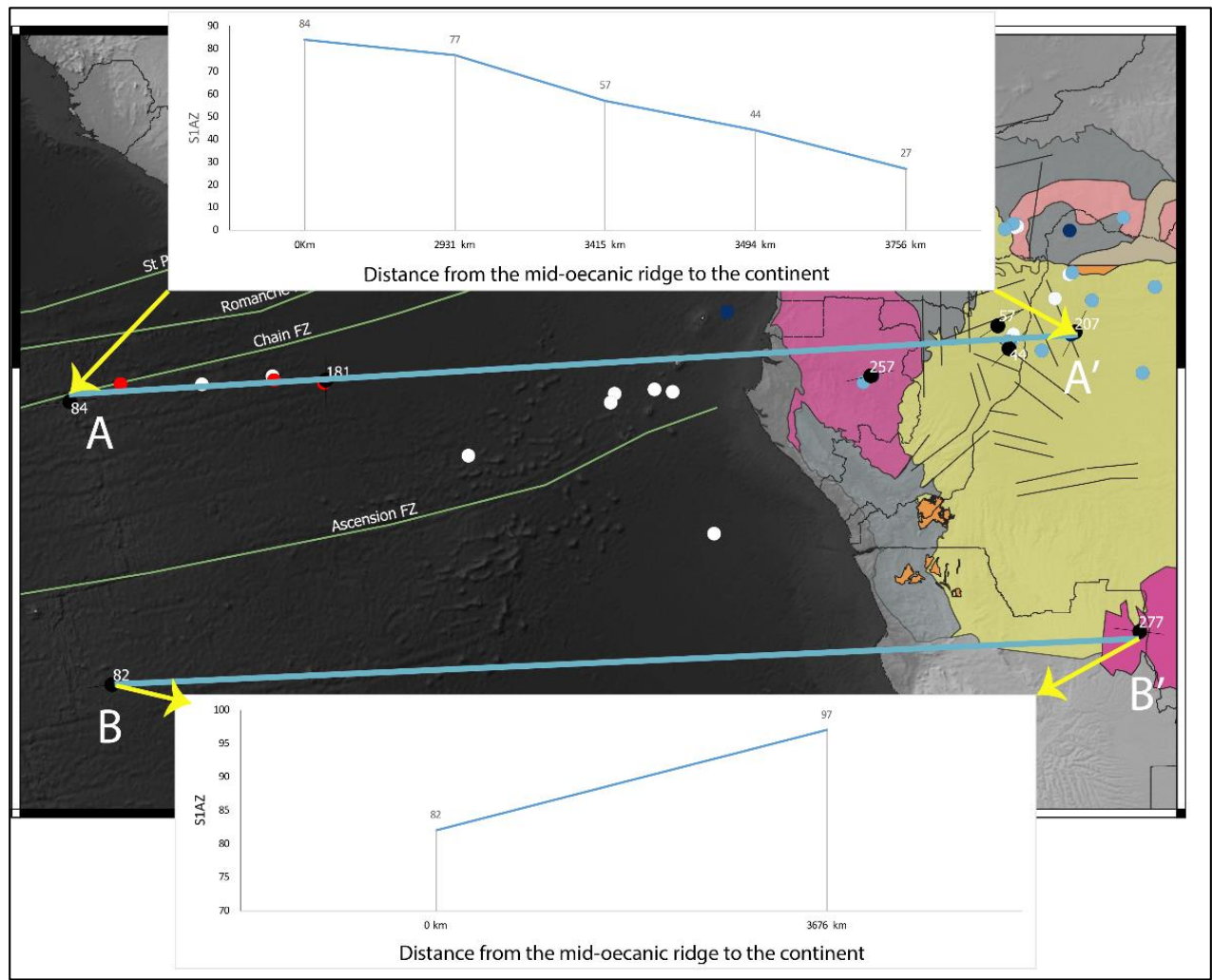

Figure 11: Azimuth variation of the principal maximum stress (S1AZ) from the mid-oceanic ridge to the continent. The zones of discontinuities are derived from the work of (Sabata, 2014)), and the earthquakes from USGS-earthquake (https://earthquake.usgs.gov/). The mapping of compressive stress regimes comes from the world stress map (Heidbach et al., 2016). The transform fault zones were redrawn from the work of (Heine et al., 2013)

\section{Discussion}

\subsection{Deformations in the Inkisi Group}

The Inkisi Group is affected essentially by brittle deformation that consists of joints and faults. Horizontal slickenlines, subvertical dip and horizontally displaced pebbles (Fig. 4b) prove the identification of strike slip faulting (Fossen, 2016; Sylvester, 1988). The presence of plumose structures on the surface of the fractures clearly indicates the presence of the joints (Hodgson, 1961; Pollard and Aydin, 1988).

The offset of a second system of fractures by the first system (Fig. 5) confirms that the second system comes later than the first. Additionally, several places in the field have shown systematic displacement of these systems ranging between 2 and $12 \mathrm{~cm}$. This observation clearly supports the conclusion that the first system is prior to the second system as shown by Miyouna et al. (2018).

270 The distinction between the two systems of fractures is clear in the field because each system develops conjugate fractures with a different orientation of the maximum principal compressive stress $\left(\sigma_{1}\right)$. In the field, the conjugate fractures related to the first system of fracture have shown a principal maximum compressive stress $\sigma_{1}$ oriented NW-SE while the conjugate fractures of the second system showed a principal maximum compressive stressoriented E-W. This is also confirmed by extension fractures along fault zone (Figs. 4a, d), as extension fractures are parallel with the direction of principal maximum compressive stress (Bons et al., 2012; Olson and Pollard, 1991; Woodcock and Schubert, 1994). The first system of fracture has shown extension fractures mainly oriented 
$\mathrm{N} 138^{\circ}$; this implies a NW-SE oriented principal maximum compressive stress for this system. The second system of fracture has shown extension mainly oriented $\mathrm{N} 280^{\circ}$, indicating that it is generated by E-W oriented stress.

The principal stresses determined in the field corroborate with those determined by the stress inversion method of the Win-Tensor program. The first stage of stress originates the first system of fracture and corresponds with the first phase of deformation (D1). It is characterized by a maximum horizontal principal compressive stress, which underwent a slight anti-clockwise rotation towards the west, from the development of joints $\left(\sigma_{1}=78 / 129^{\circ}\right)$ to the development of a system of strike slip faults $\left(\sigma_{1}=01 / 142^{\circ}\right.$, in Brazzaville), (Figs. 7a and 8a). As joints have shown similar orientation with faults and plumose structures sometimes overprinted with slickenlines, it is clearly indicated that strike slip faults evolved from joints. Therefore, the transition from an extension regime to a strike slip regime is made clear. This phenomenon of nucleation of strike slip faults from joints has also been demonstrated by Segall and Pollard, (1983) in the granites of the Sierra Nevada, and by several other authors (Kim et al., 2001; Martel, 1990). This first phase (D1) was well identified in Brazzaville. However, our observations in Kinshasa and Louingui did not allow us to determine a well-constrained tensor for this study. The studies of Delvaux et al., (2014), (2016), (2017) in Kinshasa in the DRC also clearly report this phase of deformation. The second stress stage engendered the second system of fractures. It corresponds to the second phase of deformation (D1). It is characterized by a principal maximum compressive horizontal stress, which underwent a slight clockwise rotation towards the east, from the development of the NE-SW joints (with $\sigma_{1}=80 / 040^{\circ}$ ) to the development of a system of strike slip faults (with $\sigma_{1}=05 / 078^{\circ}$, in Brazzaville). This phase (D2) is present in

295 Brazzaville (with $\sigma_{1}=05 / 078^{\circ}$, Kinshasa (with $\sigma_{1}=05 / 082$ ), and in Louingui (with $\sigma_{1}=00 / 096^{\circ}$ ) (Fig. 8). The different orientations of stresses determined for the second phase (D2) in Brazzaville, Kinshasa, and Louingui show a weak variation and are oriented in parallel in the E-W direction. The joints have only been observed in Brazzaville and Kinshasa, as the quarry cliffs have made it easier to observe fault surfaces. However, in Louingui, along the Loufoulakari River, outcrop conditions did not favor sighting of the joints.

300 Several cement masonry fences at dwellings along the Congo River show linear breaks and fractures (Fig. 6). Most of these linear breaks and fractures are parallel to the second fracture system, with orientations NE-SW to E-W. This confirms their relationship with the second fracturing phase (D2). The reactivation of this deformation phase is probably linked to seismic activities imperceptible by the population. The multiple repairs and fracturing of one fence and its foundation (Fig. 6) after our visits in 2015, 2016, and 2017 provide evidence of micro seismicity in the area. While our correlation to the bedrock fractures may be true, this type of recurrent cracking can also be due to soil conditions like presence of swelling clays or lack of adequate support in soft soils that are moving downhill. In our opinion, this seismicity should be monitored by installing seismographs.

\subsection{Congo Basin earthquakes}

310 The low frequencies and magnitudes associated with earthquakes described in our study area imply that these earthquakes originated from intraplate movement. These earthquakes are preferentially concentrated along the western passive margin of the African continent. The same types of intraplate earthquakes are also described with similar characteristics on the opposite side of the Atlantic in Brazil (Assumpção, 1998; Assumpção et al., 2004; Bezerra et al., 2014) and in Canada (Atkinson et al., 2000; Stein et al., 1979). The calculated recurrence of higher 315 magnitude earthquakes (6) on the Richter scale is twelve (12) years and that of average earthquakes (magnitudes 4 and 5) is 2 years (Fig. 9 and Table 3). This implies a real possibility of seeing the study area affected in the future by an earthquake of magnitude of at least 6 . Although passive margin earthquakes have a seismic moment of $0.5 \%$ (Sandiford and Egholm, 2008), their effects can be very dangerous (Zoback, 1999). This is the case of the 5.8 magnitude earthquake in 1989 at Newcastle in Australia along a passive margin, which caused 13 deaths and $\sim 4$

320 billion dollars in damage (Sandiford, 2003; Sandiford and Egholm, 2008). The danger is therefore very real for the RC and the DRC.

The areas of concentration of the $\mathrm{C} 1$ and $\mathrm{C} 2$ earthquakes (Fig. 10), respectively, show a link with the pre-existing faults in the Congo Basin and the Oubanguide chain in Cameroon. In zone C1, the majority of the faults of the Congolese basin or the Congo basin are steeply dipping and the NW-SE oriented sub-basins are separated by strike

325 slip faults of around $100 \mathrm{~km}$ (Giresse, 1982, 2005). These steeply dipping faults can be reactivated in the case of a strike slip regime with horizontal compression, as emphasized by the fault reactivation laws of Sibson (1985). In addition, the depth of faults in the Congo Basin (Crosby et al., 2010) corresponds to the depth of earthquake epicenters $\sim 9 \mathrm{~km}$ (Table 1). This link between earthquakes in the Congo Basin and pre-existing faults in the basin has also been suggested by Bouka Biona and Sounga, (2001). However, a determination of the in-situ stress has still not been possible. In zone C2 (Fig. 9), the earthquakes are directly linked to the dextral fault (NE-SW) of the Central African Shear Zone (CASZ), as also demonstrated by Ateba et al., (1992) and Ngatchou et al., (2018). 
The alignment of the offshore earthquakes parallel to the "Ascension" and "Chain" transform fault zones (Fig. 10) clearly demonstrates the accumulation of intraplate stresses within the African plate. This phenomenon has also been demonstrated by Wiens and Stein, (1984), suggesting that an oceanic lithosphere older than 35 Ma begins to accumulate compressive stresses responsible for earthquakes. Stress regime data in the Congo Basin area and the Atlantic Ocean passive margin show evidence of horizontal compression. Based on the results of the earthquake focal mechanism (Heidbach et al., 2016, 2018), the compression of the present-day stresses on the passive margin of the eastern Atlantic Ocean is mostly oriented E-W to NE-SW (Fig. 11). Thus, earthquakes in the Congo Basin are due to intraplate stresses originating from the E-W ridge push of the opening of the Atlantic Ocean. Several earthquakes line up almost in a straight line, from the mid-ocean ridge to the equatorial margin of the eastern Atlantic Ocean (Fig. 10). The transform fault "Ascension", of dextral movement, probably plays in transfer of stress towards the continent. The kinematics of the "Ascension" fault correspond well to that of zone $\mathrm{C} 2$.

\subsection{Link between Inkisi Group deformation and earthquakes in Congo basin}

The earthquakes recorded in the Congo Basin inevitably affected rocks throughout the study area. It should be noted that we speak of neotectonics when the faults are considered to have been active in the last 35,000 years or have been active repeatedly during the last 500,000 years (Keller and Pinter, 2002). Both determined tectonic phases have been described by several authors (Delvaux et al., 2017 ; Nkodia, 2017 ; Miyouna et al., 2018). The

350 first tectonic phase began after the end of the Paleozoic (Miyouna et al., 2018) due to a far-field propagation of the stress in south Gondwana (Delvaux, 2001; Delvaux et al., 2012) and was reactivated in the Cretaceous when the Atlantic Ocean opened. Guiraud et al. (1992), (2005) suggest that the opening of the Atlantic Ocean in Cretaceous time induced a major compression in Central Africa that has been recorded in the Benué Basin in Nigeria (Benkhelil, 1982, 1986; Guiraud et al., 1989), also in Dosa, Dosé, and the Salamat basin in Chad (Genik, 355 1992).

As the Inkisi Group is post Pan-African and pre-Karoo (Tack et al., 2008), the geodynamic events responsible for its deformation are therefore constrained to the period between the post-Karoo and present-day. In the kinematic history of the opening of the Atlantic Ocean, it is shown (Heine et al., 2013) that at about $120 \mathrm{Ma}$, compressive intraplate stresses started to accumulate on the Atlantic margins. The extension of the Atlantic oceanic rift goes 360 from NW-SE to E-W. Accumulation of intraplate stresses due to the opening of the Atlantic Ocean until the present time would therefore cause the tensor of the second deformation phase (D2) observed within the Inkisi group. This effect of the intraplate stress due to the opening of the Atlantic ocean has also been noted by the geophysical studies of Ngatchou et al., (2018) which report that the Central African shear zone in Cameroon would be reactivated by the ridge push effect caused by the opening of the Atlantic Ocean. More importantly, the stresses

365 obtained from focal mechanisms on earthquakes in the Congo basin indicate a mostly compressive regime oriented E-W with a slight strike slip component (Delvaux and Bath, 2010; Heidbach et al., 2016, 2018). The E-W orientation of the principal maximum horizontal compressive stress of the focal mechanism is parallel to that of our second phase of deformation (D2) determined in the Inkisi Group in Brazzaville, Kinkala, and Louingui (Fig. $8 \mathrm{~b}, \mathrm{c}$, and $\mathrm{d})$. Although the general tendency of the variation of the azimuth of the principal maximum compressive stress by focal mechanism shows that there are some disturbances in the propagation of the stress from the midoceanic ridge to the continent (Fig. 11), the E-W stress is preserved in most areas. This inevitably shows the western passive margin of Africa is affected by neotectonics.

The stresses from earthquake data recorded in the Congo Basin are of similar orientation with stresses associated with the second phase in the Inkisi Group as calculated in Brazzaville, Kinshasa and Louingui. This undoubtedly proves that Congo Basin earthquakes and the second phase of deformation in the Inkisi Group originated from a unique tectonic event. They have been produced by the ridge push effect of the opening of the Atlantic on the continent.

\section{Conclusion}

380 This present work shows the cities of Brazzaville and Kinshasa are affected by neotectonic activity. The Inkisi group has been affected by two tectonic phases. The first phase (D1) is oriented NW-SE. It is probably linked to two tectonic events, the far-field stress propagation in south Gondwana in the Paleozoic and the compression in the Cretaceous during the opening of the Atlantic Ocean. The second phase (D2) is oriented E-W and is linked to the opening of the Atlantic Ocean. Phase D2 is directly correlated to earthquakes recorded in the western Congo

385 Basin region, particularly in northern RC and northwestern DRC, which are caused by the ridge push effect on the continent from the opening of the Atlantic Ocean. The transform faults within the central Atlantic Ocean segment 
ensure the transfer of stress between the mid-oceanic ridge and the western passive margin in Central Africa. The cracks and fractures observed in masonry houses and fences along the Congo River, which line up mainly in the $\mathrm{NE}$ direction, are echoes of earthquakes caused by the opening of the Atlantic Ocean. It is therefore appropriate that the construction of walls and buildings considers the seismic risk of the basement rocks of Brazzaville and Kinshasa.

\section{Author contribution}

$\mathrm{HN}$ and TM, conceptualized the study, conducted the fieldwork, wrote, edited the manuscript and interpreted the results. FB was a supervisor, and designed the study methodology and acquired finding support. DD supervised the work, conducted fieldwork and validated the paleostress result, he analyzed the faults data and acquired finding support. NB conducted fieldwork in Kinkala.

\section{Acknowledgments and Data availability statement}

This work is related to Nkodia Hardy's PhD by F. Boudzoumou and D. Delvaux. They were funded by Coopération Belge and ACCORD-CAD, under GEORES4DEV program through the support of the Royal Museum of Central Africa. We would like specially to thank reviewers for their great help to improve this manuscript. We also thank Margaret Wessel for improving the English of the manuscript. The data on earthquakes in the Congo Basin can be downloaded at https://earthquake.usgs.gov/.

No potential conflict of interest was reported by the authors.

\section{References}

Alkmim, F., Marshak, S., Pedroa-Soares, A. C., Peres, G. G., Cruz, P. C. and Whittington, A.: Kinematic evolution of the Araçuai-West Congo orogen in Brazil: Nutcracker tectonics during the Neoproterozoic, Precambrian Research, 149, 43-64, 2006.

Ambraseys, N. N. and Adams, R. D.: Seismicity of West Africa, Ann. geophys., B, Terr. planet. phys, 4(6), 679$702,1986$.

Angelier, J.: From orientation to magnitudes in paleostress determinations using fault slip data, Journal of structural geology, 11(1/2), 37-50, 1989.

Angelier, J.: Fault slip analysis and Paleostress reconstruction, In Hancock, P. L., ed., Continental deformation. Pergamon, 53-100, 1994.

Assumpção, M.: Seismicity and stresses in the Brazilian passive margin, Bulletin of the Seismological Society of America, 88(1), 160-169, 1998.

420 Assumpção, M., Schimmel, M., Escalante, C., Roberto Barbosa, J., Rocha, M. and Barros, L. V.: Intraplate seismicity in SE Brazil: stress concentration in lithospheric thin spots, Geophys J Int, 159(1), 390-399, doi:10.1111/j.1365-246X.2004.02357.x, 2004.

Atkinson, G., Bakun, B., Bodin, P., Boore, D., Camer, C., Frankel, A., Gasperini, P., Gomberg, J., Hanks, T., Hermann, B., Hough, S., Johnston, A., Kenner, S., Langston, C., Linker, M., Mayne, P., Petersen, M., Powell,

425 C., Prescott, W., Schweig, E., Segall, P., Stein, S., Stuart, B., Tuttle, M. and VanArsdale, R.: Reassessing the New Madrid Seismic Zone, Eos Trans. AGU, 81(35), 397, doi:10.1029/00EO00294, 2000.

Ayele, A.: Active compressional tectonics in central Africa and implications for plate tectonic models: evidence from fault mechanism studies of the 1998 earthquakes in the Congo Basin, Journal of African Earth Sciences, 35(1), 45-50, 2002. 
Benkhelil, J.: Structure et évolution géodynamique du bassin intracontinental de la Benoué (Nigeria), Thèse Sciences, Nicè., 1986.

Bezerra, F. H. R., Rossetti, D. F., Oliveira, R. G., Medeiros, W. E., Brito Neves, B. B. de, Balsamo, F., Nogueria, F., Dantas, E. L., Andrades, F. and Géos, A. M.: Neotectonic reactivation of shear zones and implications for faulting style and geometry in the continental margin of NE Brazil, , 614, 78-90, 2014

Bons, P. D., Elburg, M. A. and Gomez-Rivas, E.: A review of the formation of tectonic veins and their microstructures, Journal of Structural Geology, 43, 33-62, 2012.

Boudzoumou, F.: La chaîne Ouest-Congolienne et son avant-pays au Congo: relations avec le Mayombien; sedimentation des sequences d'âge Protérozoïque supérieur, PhD Thesis, Thèse de doctorat, Université AixMarseille, France. 220p.[Google Scholar]., 1986.

Boudzoumou, F. and Trompette, R.: La chaine panafricaine ouest-congolienne au Congo (Afrique equatoriale); un socle polycyclique charrie sur un domaine subautochtone forme par l'aulacogene du Mayombe et le bassin de l’Ouest-Congo, Bulletin de la Société Géologique de France, 4(6), 889-896, 1988.

Bouka Biona, C. and Sounga, J.-D.: Corrélation entre la localisation des foyers des séismes et les zones de délimination des horsts et des grabens su soubassement de la Cuvette Congolaise (Afrique Centrale), Annales Université Brazzaville, 2(1), 125-139, 2001.

Brito Neves, B. B. de, Campos Neto, M. da C. and Fuck, R. A.: From Rodinia to Western Gondwana: an approach to the Brasiliano-Pan African Cycle and orogenic collage, Episodes-Newsmagazine of the International Union of Geological Sciences, 22(3), 155-166, 1999.

450 Callec, Y., Paquet, F., Issautier, B., Schroetter, J.-M., Thieblemont, D., Boudzoumou, F., Guillocheau, F., KebiTsoumou, S., Dah Tolingbonon, R. H. and Nganga Lumuamu, F.: Notice explicative de la ville de Brazzaville, Editions BRGM., 2015.

Cosson, J.: Notice explicative sur les feuilles Pointe-Noire et Brazzaville. Carte géologique de reconnaissance au 1/500 000, Bull. Dir. Mines Géol. AEF., 1955.

455 Crosby, A. G., Fishwick, S. and White, N.: Structure and evolution of the intracratonic Congo Basin, Geochemistry, Geophysics, Geosystems, 11(6), 2010.

Dadet: Notice explicative sur la carte géolgoique de la république du Congo - Brazzaville au 1/500 000, Mém. Bur. Reche. Géol. Min., Orléans , France, 70, 103, 1969.

Delpomdor, F. and Préat, A.: Overview of the Neoproterozoic Sedimentary Series Exposed Along Margins of the Congo Basin, in Geology and Resource Potential of the Congo Basin, edited by M. J. de Wit, F. Guillocheau, and M. C. J. de Wit, pp. 41-58, Springer Berlin Heidelberg, Berlin, Heidelberg., 2015.

Delvaux, D.: Karoo rifting in western Tanzania: Precursor of Gondwana breakup, Contributions to geology and paleontology of Gondwana in honor of Helmut Wopfner: Cologne, Geological Institute, University of Cologne, $111-125,2001$.

465 Delvaux, D. and Bath: African stress pattern from formal inversion of focal mechanism data, Tectonophysics, 482, 105-128, 2010.

Delvaux, D. and Sperner, B.: New aspects of tectonic stress inversion with reference to the TENSOR program, Geological Society, London, Special Publications, 212(1), 75-100, 2003.

Delvaux, D., Moeys, R., Stapel, G., Petit, C., Levi, K., Miroshnichenko, A., Ruzhich, V. and San'kov, V.:

470 Paleostress reconstructions and geodynamics of the Baikal region, Central Asia, Part 2. Cenozoic rifting,

Tectonophysics, 282(1-4), 1-38, 1997. 
Delvaux, D., Kervyn, F., Macheyeki, A. S. and Temu, E. B.: Geodynamic significance of the TRM segment in the East African Rift (W-Tanzania): Active tectonics and paleostress in the Ufipa plateau and Rukwa basin, Journal of Structural Geology, 37, 161-180, 2012.

475 Delvaux, D., Gloire, G., Mees, F. and Lahogue, P.: The use of hybrid fractures in paleostress determinations: test case with the the Palygorskite-bearing fractures in the Kinshasa area, DR Congo, in EGU General Assembly Conference Abstracts, vol. 16., 2014.

Delvaux, D., Everaerts, M., Kongota Isasi, E. and Ganza Bamulezi, G.: Intraplate compressional deformation in West-Congo and the Congo basin: related to ridge-puch from the South Atlantic spreading ridge?, in EGU General Assembly Conference Abstracts, vol. 18., 2016.

Delvaux, D., Ganza, G., Kongota, E., Fukiabantu, G., Mbokola, D., Boudzoumou, F., Miyouna, T., Gampio, U. and Nkodia, H.: The" fault of the Pool" along the Congo River between Kinshasa and Brazzaville, R (D) Congo is no more a myth: Paleostress from small-scale brittle structures, in EGU General Assembly Conference Abstracts, vol. 19, p. 15143., 2017.

485 Dunne, W. M. and Hancock, P. L.: Paleostress analysis of small scale brittle structures, In Hancock, P. L., ed., Continental deformation. Pergamon, 101-120, 1994.

Fossen, H.: Structural geology, Cambridge University Press., 2016.

Genik, G. J.: Regional framework, structural and petroleum aspects of rift basins in Niger, Chad and the Central African Republic (CAR), Tectonophysics, 213(1-2), 169-185, 1992.

490 Giresse, P.: La succession des sédiments dans les bassins marins et continentaux du Congo depuis le début du Mésozoïque, Sciences Géologiques, bulletins et mémoires, 35(4), 183-206, 1982.

Giresse, P.: Mesozoic-Cenozoic history of the Congo basin, Journal of African Earth Sciences, 43(1-3), 301315, 2005a.

Giresse, P.: Mesozoic-Cenozoic history of the Congo Basin, Journal of African Earth Sciences, 43(1-3), 301315, doi:10.1016/j.jafrearsci.2005.07.009, 2005b.

Guiraud, M., Ajakaiye, D. E. and Ugodulunwa, F. X. O.: Characterisation of Late Cretaceous NE-SW sinistral wrench faults in the upper Benue Trough (Nigeria) using microtectonic and aeromagnetic data, Journal of African Earth Sciences (and the Middle East), 9(1), 9-21, 1989.

Guiraud, R., Binks, R. M., Fairhead, J. D. and Wilson, M.: Chronology and geodynamic setting of CretaceousCenozoic rifting in West and Central Africa, Tectonophysics, 213(1-2), 227-234, 1992.

Guiraud, R., Bosworth, W., Thierry, J. and Delplanque, A.: Phanerozoic geological evolution of Northern and Central Africa: an overview, Journal of African Earth Sciences, 43(1-3), 83-143, 2005.

Heidbach, O., Rajabi, M., Reiter, K. and Zeigler, M.: World stress Map 2016, 2016.

Heidbach, O., Rajabi, M., Cui, X., Fuchs, K., Müller, B., Reinecker, J., Reiter, K., Tingay, M., Wenzel, F. and Xie, F.: The World Stress Map database release 2016: Crustal stress pattern across scales, Tectonophysics, 744, 484-498, 2018.

Heine, C., Zoethout, J. and Müller, R. D.: Kinematics of the South Atlantic rift, Solid Earth, 4(2), 215-253, doi:10.5194/se-4-215-2013, 2013.

Hodgson, R. A.: Classification of structures on joint surfaces, American journal of science, 259(7), 493-502, 1961.

Kadima, E., Delvaux, D., Sebagenzi, S. N., Tack, L. and Kabeya, S. M.: Structure and geological history of the Congo Basin: an integrated interpretation of gravity, magnetic and reflection seismic data, Basin Research, 23(5), 499-527, 2011. 
Keller, E. A. and Pinter, N.: Earthquakes, Uplift and Landscapes, 2nd edition., Printice Hall, Upper Saddle River, New Jersey., 2002.

Kim, Y.-S., Andrews, J. R. and Sanderson, D. J.: Reactivated strike-slip faults: examples from north Cornwall, UK, Tectonophysics, 340(3-4), 173-194, 2001.

Linol, B., de Wit, M. J., Milani, E. J., Guillocheau, F. and Scherer, C.: New regional correlations between the Congo, Paraná and Cape-Karoo basins of southwest Gondwana, in Geology and Resource Potential of the Congo Basin, pp. 245-268, Springer., 2015.

Martel, S. J.: formation of compound strike-slip zones, Mount Abbot quadrangle, California. journal of structural Geology, 12(7), 869-882, 1990.

Miyouna, T., Malounguila-Nganga, D. M., Essouli, O. F., Ndembé-Ndembé, A. J., Moussiessié, J. and Kinga, M.: ETUDE PALEOENVIRONNEMENTALE DES DEPOTS DETRITIQUES DE LA FORMATION DE COUVERTURE DU BASSIN COTIER DU CONGO, Sciences de la vie, de la terre et agronomie, 4(1), 2016.

Miyouna, T., Dieu-Veill Nkodia, H. M., Essouli, O. F., Dabo, M., Boudzoumou, F. and Delvaux, D.: Strike-slip deformation in the Inkisi Formation, Brazzaville, Republic of Congo, Cogent Geoscience, 4(1), 1542762, 2018.

Miyouna, T., ELENGA, H., BOUDZOUMOU, F., ESSOULI, O. F., GNIANGA, A. I. and El Hadji, S. O. W.: Dynamique sédimentaire de la formation de couverture de Pointe Noire à Brazzaville, Sud de la République du Congo, Afrique SCIENCE, 15(4), 134-155, 2019.

Moulin, M., Aslanian, D. and Unternehr, P.: A new starting point for the South and Equatorial Atlantic Ocean, Earth-Science Reviews, 98(1-2), 1-37, 2010.

Ngatchou, H. E., Nguiya, S., Owona Angue, M., Mouzong, P. M. and Tokam, A. P.: Source characterization and tectonic implications of the M4.6 Monatélé (Cameroon) earthquake of 19 March 2005, Geological Society of South Africa, 2018.

Nkodia, H. M. D.-V.: Style structurale et tectonique de la formation de l'Inkisi, Msc Thesis, Marien Ngouabi, Brazzaville, 25 July., 2017.

Olson, J. E. and Pollard, D. D.: The initiation and growth of en echelon veins, Journal of Structural Geology, 13(5), 595-608, 1991.

540 Pollard, D. D. and Aydin, A.: Progress in understanding jointing over the past century, Geological Society of America Bulletin, 100(8), 1181-1204, 1988.

Sabata, J. P.: Avancement et progrès dans l'exploration de la Cuvette Centrale. Cas du Bassin de la Cuvette congolaise, Kinshasa. [online] Available from: www.miningreview.com, 2014.

Sandiford, M.: Neotectonics of southeastern Australia: linking the Quaternary faulting record with seismicity and in situ stress. In: Hillis, R.R., Muller, D. (Eds.), Evolution and Dynamics of the Australian Plate, Geological Society of Australia Special Publication, 22, 101-113, 2003.

Sandiford, M. and Egholm, L. D.: Enhanced intraplate seismicity along continental margins: Some causes and consequences, , 457, 197-208, 2008.

Segall, P. and Pollard, D. D.: Joint formation in granitic rock of the Sierra Nevada, Geological Society of America Bulletin, 94(5), 563-575, 1983.

Sibson, R. H.: A note on fault reactivation, Journal of Structural Geology, 7(6), 751-754, 1985.

Stein, S., Sleep, R., Geller, S., Wang and Kroeger, G.: Earthquakes along the passive margin of eastern Canada, Geophys. Res. Lett., 5, 537-540, 1979.

Sylvester, A. G.: Strike-slip faults, Geological Society of America Bulletin, 100(11), 1666-1703, 1988. 
https://doi.org/10.5194/se-2020-162

Preprint. Discussion started: 5 October 2020

(c) Author(s) 2020. CC BY 4.0 License.

555 Tack, L., Delvaux, D., Kadima, E., Delpomdor, F., Tahon, A., Dumont, P., Hanon, M., Fernandez-Alonso, M., Baudet, D. and Dewaele, S.: The $1.000 \mathrm{~m}$ thick Redbeds sequence of the Congo River Basin (CRB): a generally overlooked testimony in Central Africa of post-Gondwana amalgamation (550 Ma) and pre-Karoo break-up (320 Ma), in 22nd Colloquium African Geology (CAG22), pp. 86-88., 2008.

Wiens, D. A. and Stein, S.: Intraplate seismicity and stresses in young oceanic lithosphere, Journal of Geophysical Research: Solid Earth, 89(B13), 11442-11464, 1984.

Wilson, J. T.: Did the Atlantic Close and then Re-Open?, Nature, 211(5050), 676-681, doi:10.1038/211676a0, 1966.

Woodcock, N. H. and Schubert, C.: Continental strike-slip tectonics, Continental deformation, 251-263, 1994.

Zoback, M. D.: Seismic hazard at the New Madrid Seismic Zone, Science, 285, 663, 1999. 